INDO GLOBAL JOURNAL OF

PHARMACEUTICAL SCIENCES

ISSN 2249- 1023

\title{
Dynamics of Bio Allergens Exposure in Urban Indoor Environment
}

\author{
Akshay Shankar ${ }^{1}$, Arun Yadav ${ }^{1}$, Palak Balyan ${ }^{1}$, Shuka Das ${ }^{2}$, Chirashree Ghosh ${ }^{1}$ \\ ${ }^{I}$ Department of Environmental Studies, University of Delhi, India \\ ${ }^{2}$ Department of Microbiology, University of Delhi, India
}

\begin{abstract}
Keywords
Allergens;

Streptococcus;

Staphylococcus;

Aspergillus;

Penicillium.
\end{abstract}

\begin{abstract}
Bioaerosols consists of aerosols containing microorganisms (bacteria, fungi, viruses) or organic compounds derived from microorganisms (endotoxins, metabolites, toxins and other microbial fragments), which are of natural or anthropogenic in origin. Human response to bioaerosols exposure is varied due to diverse composition of bioaerosols and which are associated with respiratory disfunction. Objective is to enumerate different bacterial and fungal fraction of bioaerosol in diverse built up environment. Two selective indoor environments with possibility of high bioaerosols emission were tagged in this study within the university campus, namely; Site I: Central Science Library (CSL) and Site II: University Health Centre (UHC). Sampling was done in three seasons (Pre-monsoon, Monsoon and post monsoon) at the height of human exposure using gravitational plate technique. Blood Agar Medium was used in the Petri dishes and sampling was done twice in a week for 10 minutes. Plates were incubated for $48 \mathrm{hr}$ at $37^{\circ} \mathrm{C}$ and then colonies were morphologically identified using specific staining method for bacteria and fungus. The results were statistically analyzed using SPSS. The result showed that University Health Centre (Site 2) $(427 \pm 38.59$ $\left.\mathrm{cfu} / \mathrm{dm}^{2} / \mathrm{hr}\right)$ had high microbial abundance than University Library (site 1) $\left(265 \pm 33.08 \mathrm{cfu} / \mathrm{dm}^{2} / \mathrm{hr}\right)$ may be at health centre patients with different infection could be the probable sources of high bioaerosols concentration. Seasonally among recorded species, abundant bacterial grows were Streptococcus and Staphylococcus, where as fungal populations were Aspergillus and Penicillium. Spatio temporal varition of indoor environment showed that bioaerosols concentration was much higher in monsoon (Site I- $207 \pm 44$.16, Site II- 597 \pm 10.11 ) than post monsoon (Site I- 151 \pm 96.4 , Site II- 371 \pm 163.12 ) and least in pre monsoon (Site I- 116 \pm 16.01 , Site II- 256 \pm 56.96$)$ also high humidity $(66.78 \pm 6.95)$ in monsoon season favour growth of microbes with optimum temperature (33.1 \pm 3.13$)$. The microbiological quality of indoor air is a significant parameter for upsurging respiratory health issues. Regular microbial monitoring can represent an useful tool to assess indoor environmental quality and can also identify critical situations which require corrective intervention. (C) 2016 iGlobal Research and Publishing Foundation. All rights reserved.
\end{abstract}

Conference Proceedings: International Conference on Advances in Plant and Microbial Biotechnology (PMB2017); JIIT, Noida: February 02-04, 2017

Indo Global Journal of Pharmaceutical Sciences( ISSN 22491023 ; CODEN- IGJPAI; NLM ID: 101610675) indexed and abstracted in EMBASE(Elsevier), SCIRUS(Elsevier),CABI, CAB Abstracts, Chemical Abstract Services(CAS), American Chemical Society(ACS), Index Copernicus, EBSCO, DOAJ, Google Scholar and many more. For further details, visit http://iglobaljournal.com 